\title{
Charter Checks and Parliamentary Balances
}

\section{Dennis Baker \& Rainer Knopff*}

\section{Introduction}

According to its most enthusiastic supporters, the Canadian Charter of Rights and Freedoms ${ }^{1}$ fulfills two major functions in Canada's democratic regime: 1 ) it shields minorities from the excesses of majoritarian decision-making, in effect guarding against the famous "tyranny of the majority"; and 2) it shields the majority from the excesses of power concentrated in the Canadian executive ("executive dictatorship"). While these two claims are in considerable tension with each other, there is an even more important conflict between each of them and the widely-accepted notion that most Charter cases arise from reasonable disagreements over correct policy. It is difficult to work through these overlapping tensions without questioning the orthodoxy that judicial power under the Charter compensates for the lack of moderating checks and balances within our parliamentary system of government. To question that orthodoxy is in turn to rediscover the merits of an older view, dating back to the founders, that did not consider the idea of parliamentary checks and balances to be an oxymoron. The rediscovery of parliamentary checks and balances does not imply the undesirability of additional judicial checks, but it does require a more nuanced understanding of those checks than the orthodoxy provides.

\section{Tyranny of the Majority, Executive Dictatorship, or}

\section{Reasonable Disagreement?}

Does the Charter prevent the tyranny of the majority or does it help the majority prevail over executive dictatorship? "As elected institutions," says Kent Roach, legislatures "have an interest in maximizing the rights of more popular groups" at the expense of less popular ones. ${ }^{2}$ This line of argument rightly maintains that our regime is not simply democratic in the sense of populist majoritarianism. Instead, ours is a liberal or constitutional democracy that seeks to forestall the tyranny of the majority through institutional checks and balances - in this case a Charterempowered judiciary checking and balancing a democratically responsive legislature.

The alternative view sees the legislative process not as dangerously responsive to majority opinion, but rather as unresponsive to the majority. For example, Joseph Fletcher \& Paul Howe, and Lorne Sossin maintain that court rulings on gay rights issues often correspond more accurately to public opinion than do legislative measures. ${ }^{3}$ For Sossin, judicial action in these instances merely "accelerates" desirable and virtually inevitable change. In this view, Charter challenges provide a means for the expression of popular will when a publicly unresponsive legislature stands in the way. ${ }^{4}$

Why are legislatures less responsive to the majority than courts in this second view? Because, rather than being truly representative, legislatures have become de facto executive dictatorships. "[M]uch public decision-making no 
longer occurs in Parliament," Martha Jackman writes; "[m]any of the decisions which have the greatest impact on individual welfare are made by Cabinet and by other parliamentary delegates within government departments, administrative agencies, and quasi-governmental bodies," she continues. ${ }^{5}$ In parliamentary systems, Trevor Allan suggests, "ii]t seems necessary ... to match executive discretion with judicial discretion," so that judges can offer "genuine protection from abuse of executive power." ${ }^{\text {" In a }}$ similar vein, Ian Greene et al. upbraid Charter skeptics for failing "to recognize the essentially corrective role of the courts in a system of parliamentary majority rule where the executive dominates the policy process,"7 and Lorne Sossin maintains that "a robust and independent judiciary" is one of the few "external checks" on the "very small group of very powerful individuals [who] shape the policy and politics of the country." Here again, we find a checks and balances perspective at work, only this time the judiciary is checking not the legislative tendency towards democratic tyranny but the executive dictatorship's flouting of public will.

Clearly, the view of Canada's founders that rights would be protected through checks and balances within the parliamentary system of government no longer prevails. Richard Cartwright expressed the founding perspective during the Confederation debates, maintaining that parliamentary government was replete "with safeguards - with latent checks of all kinds - checks established, many of them, more by custom and usage than by positive law - as to make it all but impossible for any majority, however strong, to perpetrate any gross act of injustice on a minority." According to our contemporary orthodoxy, by contrast, the so-called "fusion" of legislative and executive branches under responsible government, together with the absence (provincially) or practical insignificance (federally) of bicameralism, means that the only serious checks and balances in our system are found in the interaction between the parliamentary and judicial branches of government, not within parliamentary institutions themselves. Both the tyranny of the majority and the executive dictatorship defences of Charter-based judicial power rest on this orthodoxy.
The internally unchecked Parliament is feared in the one case as the vehicle of majority excess, and in the other as the vehicle of democratically unresponsive elites; in either case, a judiciary enforcing the Charter is viewed as the only realistic check on parliamentary excess.

Despite this common ground, there is an obvious tension between the tyranny-of-the majority and the executive-dictatorship justifications of a Charter-enhanced judicial check in our system of government: one argument seeks to restrain the majority, the other seeks to liberate it. Elsewhere, one of us has explored this tension at length; ${ }^{10}$ here we set it aside - assuming for argument's sake that the Charter protects us against either or perhaps both majority tyranny and executive dictatorship - in order to focus on the tension between each of these views and a third widely accepted claim, namely, that Charter issues are generally matters of reasonable disagreement.

Peter Russell pioneered this third claim in Canada in his seminal article "The Political Purposes of the Charter," which maintained that most Charter cases deal not with the core of rights but rather with issues arising at their periphery. ${ }^{11}$ At this periphery, there is room for legitimate disagreement where neither side has a monopoly on rationality and where both sides present positions at least plausibly consistent with the Constitution. Many, if not most, scholars have since followed Russell's lead. For example, in The Supreme Court on Trial, Kent Roach devotes an entire chapter to the "myth of right answers." 2 Ian Greene similarly maintains that there tend to be reasonable arguments on both sides of Charter issues. ${ }^{13}$ And Janet Hiebert's work is thoroughly infused by the conviction that the basic normative ideals and values represented by the Charter "give rise to different, but nevertheless reasonable, interpretations." ${ }^{4}$

But here we encounter a puzzle: How is it that the legislative tyranny of the majority or our executive dictatorship generally produces policies within the realm of reasonable disagreement? In fact, if either or both of these images - tyranny of the majority and executive dictatorship - were accurate, we could not plausibly expect most policy to fall within the 
bounds of "reasonable disagreement." Instead, we would expect to find a court knocking down egregious and immoderate laws on clearly mandated constitutional grounds. Simply put, if it is true that Charter issues do generally fall within the bounds of reasonable disagreement, both the tyranny of the majority and executive dictatorship claims must be crude oversimplifications of our legislative-executive complex. Put slightly differently, if the reasonable differences view holds, can it be because there are more non-judicial checks and balances at work in our parliamentary institutions than are generally acknowledged? Is the founding view expressed by Richard Cartwright perhaps not as outdated as our current orthodoxy assumes?

How else do we explain Canada's long history of policy moderation prior to the enactment of the Charter? Over the course of Canada's constitutional history, it has been legislatures, not courts, that have taken the leading role in securing civil rights and liberties. Prior to being "saved by the Charter" in 1982, Canadians were protected by progressive due process legislation (the Canada Evidence Act ${ }^{15}$ and the Young Offenders $A c t^{16}$ being two pre-Charter milestones), statutory human rights codes (the Ontario $\mathrm{Hu}$ man Rights Code, ${ }^{17}$ for example, has been in force since 1962), and by a variety of ancillary legislation. As Peter Hogg points out, Canada's pre-1982 record on civil liberties "while far from perfect, seems to be much better than that of most of the countries in the world, although nearly all countries have bills of rights in their constitutions." ${ }^{18}$ Hogg argues that "[t]he basic reason for this has very little to do with the contents of Canada's (or any other country's) constitutional law," but rather with "the democratic character of Canada's political institutions, supported by long traditions of free elections, opposition parties and a free press." ${ }^{\prime 19}$ (One might have thought that Canada's political institutions would be part of the "content of Canada's constitutional law" but such is the state of modern Canadian constitutional thinking).

If, as Hogg contends, Canada's representative institutions were capable (though not "perfect") protectors of civil liberties before 1982, is there any reason to suppose that they do not continue to play a significant role in ensuring moderate policy outcomes in the Charter era? Ironically, according to some, the Charter itself may have caused the political process to become less moderate. "One of the unfortunate consequences of the Charter," argues Kent Roach, "is that Parliament has abdicated its proactive law reform role and increasingly relies on the Court to articulate and enforce minimum standards of fairness for the accused." ${ }^{20}$ In other words, the Charter frees the legislative process to become more extreme than it might have been absent the Charter. Perhaps, but to the extent that the legislative process continues to pose questions of reasonable disagreement to the courts, might we not reasonably assume that moderating forces internal to that process are still at work? Unless, of course, it is the prospect of judicial invalidation itself that encourages moderation within the legislative process, but that view sits rather uneasily with the claim that the same prospect liberates legislatures from their restraint. And why, one might wonder, would either a tyrannical majority or an executive dictator (i.e., an executive prepared to ignore backbenchers) fear judges? No, the possibility that the institution that throws up questions of "reasonable disagreement" has sources of moderation within itself cannot be dismissed out of hand. Not that our parliamentary institutions could not be improved, we hasten to add. But improvement must be undertaken with full awareness of existing strengths as well as weaknesses. We need a better appreciation of how, even in our flawed system, legislative outcomes tend to be kept within the bounds of reasonable disagreement before any court has its say.

\section{Parliamentary Checks and Balances}

There is no better place to begin than with the often forgotten insight of a previous generation of institutional scholars, represented in R. MacGregor Dawson \& Norman Ward's statement that first ministers - our executive dictators - will be "sufficiently wise and far-seeing to limit [their] demands ... to those which will gain the general acceptance of [their parliamentary] followers." ${ }^{21}$ Even trained seals, in other words, can be pushed too far. Does this 
intra-parliamentary check explain the moderate policy outcomes which ground the "reasonable disagreement" view of Charter disputes? To address this question, imagine a prime minister with such truly extremist inclinations that his legislative agenda involved questions at the core rather than the periphery of our constitutional rights. Unless this prime minister has the courage to overthrow the constitution altogether, he can impose his policy preferences only by persuading Parliament to enact them (and, subsequently, the bureaucracy to execute them in the way he prefers). Dawson \& Ward note that while "general acquiescence [to a prime minister's wishes] can within limits be assumed... this co-operation is usually given with some reserve, and the possibility of dissatisfaction and even revolt, though it may be remote, is never entirely absent." 22 As Scott Gordon argues in the British context, if the prime minister "is a dictator, he is a singularly curious one: unable to determine state policy unilaterally, required to endure unremitting and unrestrained public criticism, and subject to dismissal without a shot being fired." 23 A similar critique might be leveled at Jeffrey Simpson's description of the Canadian prime minister as a "friendly dictator"; "restrained" might be a better qualifier than "friendly." 24

Evidence for this can be found even in Donald Savoie's Governing from the Centre, the book most often used to support the proposition that an all-powerful prime minister faces no serious check from Parliament. ${ }^{25}$ Savoie's other major theme - the centre's lack of policy ambition in favour of management of the status quo - is rarely referenced. One might ask why Jean Chrétien, Savoie's most centralizing prime minister and the basis of Simpson's "friendly dictator," is also criticized by Savoie for being "the managerial prime minister." Savoie describes Chrétien's "managerial mindset" as notably eager to "avoid bold initiatives or attempts to lead the country in redefining itself." ${ }^{26}$ With respect to its legislative agenda, it is difficult to argue that the Chrétien government took full advantage of its supposed power. Savoie himself, alert to this curiosity, argued that it was a function of external limitations, particularly the central bureaucracy's intense desire to avoid media gaffes. However, as Chrétien bemoaned, management of the caucus is itself a source of media interest: "If I impose a decision, you say I am a dictator, and if I listen to them, the caucus is split." ${ }^{27}$ Given its internalization into prime ministerial thinking and planning, it is difficult to conclude that the formal power of the Commons over the prime minister plays no part in hemming in executive power.

One might note, in this regard, that although the formal power of Parliament to oppose the prime minister is rarely overtly manifested, prime ministers are occasionally reminded of its reality. In Chrétien's case, his final term (20002004) included two publicly visible examples of such challenges: the addition of sunset clauses to the anti-terrorism bill, ${ }^{28}$ and the amendments to the species-at-risk legislation. ${ }^{29}$ These successful challenges, made against a prime minister freshly elected (in November 2000) with a 106 seat advantage over the Official Opposition, demonstrate that the centre is not as hopelessly beyond any formal controls available to legislators as Charter enthusiasts might assume.

The first example - the amendments to the Chrétien government's anti-terrorism package - is a powerful one since it is reasonable to assume that the executive's hand might be stronger when there is a palpable sense of "emergency" as there was following 11 September 2001. The Government responded to the heightened threat of terrorism with two pieces of legislation: Bill C-36, ${ }^{30}$ primarily addressing the need for additional police powers, and Bill C-42, ${ }^{31}$ primarily addressing the need for additional public safety measures. The latter proved to be so poorly drafted and unpopular that the Government abandoned it in favour of new public safety legislation in the Spring of 2005. ${ }^{32}$ The former, however, was strongly supported by Prime Minister Chrétien and Justice Minister Anne McLellan. In particular, Chrétien and McLellan insisted that, despite Bill C-36's constitutionally questionable changes to police procedure (such as the use of "preventative arrest"), it was unwise to attach a sunset clause, which would have extinguished the Act after a set period, thus requiring a reenactment by a future Parliament to remain in force. Prime Minister 
Chrétien was particularly dismissive of this proposal, declaring that a sunset clause was inappropriate because "we don't know when terrorism will be over." 33 This position became increasingly untenable as academic criticism of Bill C-36 began to mount. A well-publicized conference at the Faculty of Law, University of Toronto, included a forceful critique of the legislation by Liberal backbencher and constitutional law professor Irwin Cotler. ${ }^{34}$ Nevertheless, Chrétien continued to oppose a sunset clause; at a private caucus meeting in November 2001, he dressed down his backbench critics and firmly rejected their demand for such a clause. "I think he pretty well closed the door on the sunset clause," leaked one MP, but added that "I don't think MPs have given up." ${ }^{35}$ If the executive dictatorship view were true, it should have been easy for Chrétien to follow through on his publicly stated commitment and resist the demands of his backbenchers. In reality, however, the centre of government could not simply impose its preference: "Bowing to intense public pressure and forces within her own caucus, Justice Minister Anne McClellan ... presented a handful of amendments to Bill C-36 that eased most of the concerns of Liberal MPs and the Canadian Alliance ..."36 By leading the charge, one newspaper account suggested, Irwin Cotler "set a new benchmark on how far a backbencher can confront his own government and live to tell the tale." ${ }^{37}$ It is telling that when the Anti-Terrorism Act' $\mathrm{s}^{38}$ most controversial measures were removed from the statute, it was by parliamentary review and not by judicial intervention.

The Government's retreat on the sunset clause was echoed in its maneuvering over species-at-risk legislation in 2002. In that case, the Chrétien government introduced Bill C- $5^{39}$ to meet Canada's international obligations, promised in 1992, for the preservation of endangered species. Upon consideration of the bill, the House environment committee suggested over 100 amendments - mainly addressing the contentious issues of landowner compensation, aboriginal administration of the law, and mandatory wildlife preservation on federal lands - but the Cabinet reversed almost every one of the committee's recommendations. ${ }^{40}$ The Government's strategy was simply to "ram it through the House of Commons" over the objections of the committee. ${ }^{41}$ This approach alienated backbench Liberals, who generally fell into two camps within the caucus: an environmentalist camp, which argued that the legislation did not go far enough in protecting endangered species, and a camp of rural members concerned with the property rights of their constituents. In the months following the committee report, the Government attempted to assuage critics by establishing an Aboriginal commission to oversee the enforcement of the Act (as demanded by Liberal backbench MP Rick Laliberte), and by making a binding commitment that specific regulations for landowner compensation would be forthcoming (as demanded by the rural caucus, led by MP Murray Calder). ${ }^{42}$ The Government was unsure that, even with these major concessions, it would have the unanimous support of the Liberal caucus or, indeed, that the Act would pass at all. Nevertheless, Environment Minister David Anderson publicly declared that there would be no more changes to the bill. ${ }^{43}$ On the eve of the vote, the Government blinked and capitulated to the environmentalist members of the caucus by accepting two key amendments (the federal government would protect species on federal property and Cabinet would be given a nine-month deadline to determine whether a species warranted protection). ${ }^{44}$ With these changes, the Act passed by a vote of 148-85. Chrétien suggested that his role in the process was less dominant than the friendly dictator characterization implies: "My caucus - they have views. They are there for that and sometimes one group doesn't agree with the other and it's the beauty of my job: I sit between them all the time and eventually we find a solution." ${ }^{45}$ One thing is certain: in the case of the species-at-risk bill, Cabinet did not simply get its way, as the "fusion" model predicts. In a candid interview months later, Minister Anderson felt "he should have held firm on the endangered species bill" and even though he was "glad it passed" he would not check his "skepticism about some of the proposals... simply because they were ultimately accepted. It's not because I was persuaded they were all right." ${ }^{\text {6 } 6}$

No one would suggest, of course, that the backbench influence over the anti-terrorism 
legislation or the Species at Risk $A c t^{47}$ is typical of the Canadian legislative process. These are exceptional cases that prove the rule of executive domination, but they also demonstrate that the formal power of legislators to reject executive demands sets outer limits to what the executive is likely to attempt or achieve. Without the power to check the executive's proposals before they become law, it is doubtful that backbenchers would have influenced the anti-terrorism and species-at-risk debates as much as they did. A significant number (approximately 30 percent in the last three majority Parliaments) of government bills introduced never receive Royal Assent. ${ }^{48}$ Even though a presumably large (but unknown) number of these bills are voluntarily abandoned by the government (lost through prorogation, etc.), the burden of the legislative process is clear. Any government would surely prefer to govern without the formal requirement that it govern through legislation approved by Parliament. The fact that they cannot, and do not do so reflects the reality of parliamentary checks and balances and the internalization of their moderating demands.

\section{Conclusion}

One need not choose between legislative and judicial checks as moderating influences in our political system. Indeed, Canadians would be well served by multiple and overlapping checks and balances. It is the portrayal of Charterbased judicial power as the only effective moderating check (on either majority tyranny or executive dictatorship) that cannot be sustained. It may be true, as Chief Justice McLachlin of the Supreme Court of Canada says, that the Charter performs "a healthy function in allowing our differences to be aired and resolved in a peaceful way, rather than by oppression and violence,"49 but it is difficult to believe that the courts' settlement of reasonable disagreements is all that stands between us and chaos. The politics of representative government offers a non-judicial (but still peaceful) way of resolving differences that similarly avoids "oppression and violence." Judicial power under the Charter may make an important contribution to our system of checks and balances, but treating it as the only (or even the main) barrier against the forces of majority tyranny or executive dictatorship is both nonsensical and counterproductive.

\section{Notes}

* Dennis Baker, Department of Political Science, University of Guelph; Rainer Knopff, Department of Political Science, University of Calgary.

1 Part I of the Constitution Act, 1982, being Schedule B to the Canada Act 1982 (U.K.), 1982, c. 11 [Charter].

2 Kent Roach, "Constitutional and Common Law Dialogues between the Supreme Court and Canadian Legislatures" (2001) 80 Canadian Bar Review 481 at 529.

3 Joseph F. Fletcher \& Paul Howe, "Supreme Court Cases and Court Support: the State of Canadian Public Opinion" (2000) 63 Choices 30 at 37-42; Lorne Sossin, "Courting the Right," Book Review of The Charter Revolution \& The Court Party by F.L. Morton \& Rainer Knopff, (2000) 38 Osgoode Hall Law Journal 531.

$4 \quad$ Ibid.

5 Martha Jackman, "The Cabinet and the Constitution: Participatory Rights and Charter Interests: Manicom v. County of Oxford" (1990) 35 McGill Law Journal 943 at 945.

6 T. R. S. Allan, Law, Liberty, and Justice: The Legal Foundations of British Constitutionalism (Oxford: Clarendon Press, 1993) at 8.

7 Ian Greene et al., Final Appeal: Decision-Making in Canadian Courts of Appeal (Toronto: James Lorimer \& Company, 1998) at 6.

8 Lorne Sossin, "The Ambivalence of Executive Power in Canada" in P.P. Craig \& Adam Tomkins, eds., The Executive and Public Law: Power and Accountability in Comparative Perspective (Oxford: Oxford University Press, 2006) at 52.

9 Janet Ajzenstat, ed., Canada's Founding Debates (Toronto: Stoddart, 1999) at 19.

10 Rainer Knopff, "How Democratic is the Charter? And Does it Matter?" in Joseph Eliot Magnet et al., The Charter of Rights and Freedoms: Reflections on the Charter After Twenty Years (Markham, Ontario: Butterworths, 2003).

11 Peter H. Russell, "The Political Purposes of the Canadian Charter of Rights and Freedoms" (1983) 61 The Canadian Bar Review 30.

12 Kent Roach, The Supreme Court on Trial: Judicial Activism or Democratic Dialogue (Toronto: Irwin Law, 2001).

13 Ian Greene, The Courts (Vancouver, B.C.: UBC 
Press, 2006) at 146.

14 Janet L. Hiebert, Charter Conflicts: What is Parliament's Role? (Montréal: McGill-Queen's University Press, 2002) at 72.

15 Canada Evidence Act, R.S.C. 1985, c. C-5.

16 Bill C-61, The Young Offenders Act, was introduced on February 16, 1981 and was given Royal Assent in July of 1982. Therefore, the genesis and drafting of the Bill can be described accurately as "pre-Charter" even if its official enactment comes shortly after the Charter arrives. Young Offenders Act, 19808182 83, (Can.), c. 110; Young Offenders Act, R.S.C., 1985, c. Y 1.

17 Ontario Human Rights Code, R.S.O. 1990, c. H19.

18 Peter W. Hogg, Constitutional Law of Canada, 4th ed. (Scarborough, Ontario: Carswell, 1997) at 31-33.

John White disagrees and suggests that Canada's record is marred by too many instances of "political passion directed at conspicuous minorities," in John White, "Not Standing for Notwithstanding” in Mark William Charlton \& Paul Frederick Barker, eds., Crosscurrents 1: contemporary political issues (Scarborough, Ontario: Nelson Canada, 1991) at 66. Janet Ajzenstat, "Reconciling Parliament and Rights: A. V. Dicey Reads the Canadian Charter of Rights and Freedoms" (1997) 30 Canadian Journal of Political Science 645 at 658 .

19 Hogg, ibid. at 31-33.

20 Roach, supra note 2 at 182. Mark Tushnet makes a similar observation but argues that "judicial overhang" is an argument against judicial interpretive supremacy. See Mark V. Tushnet, Taking the Constitution Away from The Courts (Princeton: Princeton University Press, 1999); Mark V. Tushnet, "Legislative and Judicial Interpretation" in Richard W. Bauman and Tsvi Kahana, eds., The Least Examined Branch: The Role of Legislatures in the Constitutional State (Cambridge; New York: Cambridge University Press, 2006) at 357.

21 Robert MacGregor Dawson, W. F. Dawson \& Norman Ward, Democratic Government in Cana$d a, 5$ th ed. (Toronto: University of Toronto Press, 1989) at 47.

22 Ibid.

23 Scott Gordon, Controlling the State: Constitutionalism from Ancient Athens to Today (Cambridge, Massachusetts: Harvard University Press, 1999) at 336.

24 Jeffrey Simpson, The Friendly Dictatorship (Toronto: McClelland \& Stewart, 2001).
The Concentration of Power in Canadian Politics (Toronto: University of Toronto Press, 1999). Cited by Robin Elliot, “The Charter Revolution and the Court Party': Sound Critical Analysis or Blinkered Political Polemic?” (2002) 35 University of British Columbia Law Review 273 at 325, n. 185; James B. Kelly, Governing with the Charter: Legislative and Judicial Activism and Framers' Intent (Vancouver: UBC Press, 2005) at 225-26.

26 Donald J. Savoie, “The Managerial Prime Minister” Policy Options (November 2000) 10.

27 Steven Chase, "Endangered species bill trouble" The Globe and Mail (1 May 2002) A5.

28 Janice Tibbetts and Jim Bronskill, “Terror bill gets facelift: Minister offers a 5-year sunset clause on some provisions, refines wording" The Gazette (21 November 2001) A13.

29 Kate Jaimet, "Liberals demanded favours to pass bill” The Ottawa Citizen (27 December 2002) A1 [Favours].

30 Bill C-36, An Act to amend the Criminal Code, the Official Secrets Act, the Canada Evidence Act, the Proceeds of Crime (Money Laundering) Act and other Acts, and to enact measure respecting the registration of charities in order to combat terrorism, $1^{\text {st }}$ sess. $37^{\text {th }}$ Parl., 2001.

31 Bill C-42, An Act to amend certain Acts of Canada, and to enact measures for implementing the Biological and Toxin Weapons convention, in order to ensure public safety, $1^{\text {st }}$ sess., $37^{\text {th }}$ Parl., 2001.

32 Bill C-6, An Act to establish the Department of Public Safety and Emergency Preparedness and to amend or repeal certain Acts, $1^{\text {st }}$ sess., $38^{\text {th }}$ Parl., 2005.

33 Janice Tibbetts, "PM rejects 'sunset clause' in terror law” The Ottawa Citizen (22 October 2001) A5.

34 Held November $9^{\text {th }}$ and $10^{\text {th }}, 2001$. The essays presented at this conference can be found in Ronald J. Daniels, Patrick Macklem \& Kent Roach, eds., The Security of Freedom: Essays on Canada's Anti-terrorism Bill (Toronto: University of Toronto Press, 2001). Cotler's contribution to this volume is entitled "Thinking Outside the Box: Foundational Principles for a Counter-Terrorism Law and Policy."

35 Shawn McCarthy, "No sunset clause for antiterror bill, PM tells his caucus" The Globe and Mail (1 November 2001) A7.

36 Daniel Leblanc, "Ottawa softens terror bill” The Globe and Mail (21 November 2001) A1 [emphasis added].

37 Philip Authier, "The man in the middle: Civilrights lawyer trod a fine line in debate" The 
Gazette (8 December 2001) B4.

38 S.C. 2001, c. 41.

39 Bill C-5, An Act respecting the protection of wildlife species at risk in Canada, $2^{\text {nd }}$ sess., $37^{\text {th }}$ Parl, 2002.

40 Kate Jaimet, "Species at risk bill gets House's OK: Compromises calm Grit turmoil” Calgary Herald (12 June 2002) A5 [Jaimet, "Species at risk"].

41 Chase, supra note 27.

42 Jaimet, "Species at risk" supra note 40.

43 Ibid.

44 Ibid.

45 Chase, supra note 27.

46 Jaimet, "Favours," supra note 29.

47 S.C. 2002 , c. 29.

48 Government of Canada, Table of Legislation Introduced and Passed by Session, online: $<$ http:// www2.parl.gc.ca/Parlinfo/compilations/HouseOfCommons/BillSummary.aspx?Language $=\mathrm{E}>$. See also, Craig Forcese \& Aaron Freeman, The Laws of Government: The Legal Foundations of Canadian Democracy (Toronto: Irwin Law, 2005) at 638 .

49 Beverly McLachlin, "The Charter 25 Years Later: The Good, the Bad, and the Challenges" (2007) 45 Osgoode Hall Law Journal 365 at 370 (approvingly citing the work of Philip Pettit). 